After tea, Mr E T. Newton proposed the usual votes of thanks, which were duly acknowledged. A portion of the party afterwards followed the Director to a fine section in the Folkestone Sands which were capped by Drift from which good examples of mammalian remains are frequently exhumed.

The station was reached by way of the river, which constitutes one of the prettiest walks connected with Aylesford and this part of the Medway. Immediately outside the station many tons of Kentish Rag, quarried from the Hythe Beds near by, were to be seen. The stones vere crowded with casts of Trigonia, Nautilus, etc.

With the exception of a slight shower the weather had remained all that could be desired, and after a most enjoyable day, in which the walking powers of the members were tested, the return journey was made at $75 \mathrm{I}$ p.m.

\title{
REFERENCES
}

Geological Survey Map, Sheet 6

Ordnance Survey Map, New Series, Sheet 272, Is

1872 WhItaker, W - "Geology of London Basin" Mem Geol Sitrvey, vol iv

I 887 WoOUWARD, H B - "Geology of England and Wales."

1900. Dibler, G E-"Zonal Features of the Chalk Pits in Rochester, Gravesend, and Croydon Areas" Proc. Geol issoc, vol. xvi, $\mathrm{p}+84$ (Patt 1x, Is)

\section{EXCURSION TO THE LAINDON HILLS, ESSEX.}

$$
\text { JULY I3TH, I907. }
$$

Director A. E. Salter, D Sc., F.G.S.

Excursion Secretary: T. W. READER

(Report by THE DIRECTOR.)

A PARTY of 35 left Fenchurch Street Station at 2.30 for Laindon Station and arrived about 330 . Several members of the Essex Field Club were present by invitation. At the station the Director referred to the bortng mentioned in the account of the last excursion in I 888 ( $c f$. references), when 342 feet of London Clay were passed through before reaching the Lower London Tertiaries. The station is about 148 feet O D. At Mr. C. T. Johnson's brickyard, about 300 feet O.D, some redistııuted London Clay was seen, and a well pointed out which had been dug for 27 feet chiefly in London Clay A good supply of water was obtained after passing a bed of septaria The outcrop of the Bagshot Sands being quite close it is probable that the occurence of water in such a position is due to slipping, similar to that seen later on 
at One Tree Hill. The septaria, which had been preserved by Mr. Johnson, yielded a good deal of teredo-bored wood. A stream near by, issuing from a spring, had formed a small, wellmarked valley. Other springs along the junction of the Bagshot Sands and London Clay were pointed out, and Dr Thresh's report on the water supply of this district referred to

The party now proceeded to a section showing about $\mathrm{r}_{5}$ feet of Bagshot Sands situated on the right of the road leading to Lee Chapel The sands are capped by one or two feet of hill-wash.

The Director stated that the sands were micaceous and pointed to some clay bands on the west side such as are characteristic of Bagshot deposits, and are well seen at Hampstead. He invited the members to search for fossils as he understood none had yet been found. Messis J Francis and H A Rigg were soon fortunate enough to find two casts of lamellibranch shells hardened by oxide of iron, and others of the party found more or less determinable fragments of casts of shells. A deta1led and prolonged examination of this pit would no doubt lead to good results. This is the second occasion upon which members of the Association have detected fossils in the Bagshot Beds of Essex (cf. Proc Geol Assoc, vol xi, p I 3, and vol. xix, p. 319) The specimens were kındly handed to Mr Cole, Hon Sec of the Essex Field Club, for its museum

At the top of the hill ( 385 feet O.D ) near the "Crown" the fine view northward was much appreciated, the hills about Brentwood, Billericay, Beggar Hill, and Danbury pointed out, and the gravel formation in the higher parts referred to

The party then proceeded to a small gravel section near the "Crown." The Director pointed out that the gravel was composed of Tertiary flint pebbles, sub-angular flints, and sub-angular and rounded pieces of Lower Greensand Chert. He regarded it as the deposit of an old stream having connection with the Wealden area, and that the hill on which they were standing owed its existence as such to the strata below having been preserved by the gravel while all around the strata not so covered has been denuded away.

Another sand-pit on the left of the road to Dry Street and Vange was then visited. The clayey bands at the top were well shown, but no fosslls were found The Director pointed out that the beds were lying flat, thus differing from those seen in the next pit.

After walkıng about a mile the road on the right to Stanfordle-Hope was taken, and a pit at One Tree Hill seen. It was pointed out that the strata was much disturbed owmg to slipping. A fine example of a small fault was seen, and also the spot about $6 \mathrm{ft}$ below the surface from which the Director had obtained a large portion of a human skull and other bones

Between 4 and $5 \mathrm{ft}$ of hill creep was above the bones, which 
were all in the Bagshot Sand, the skull being full of sand. Although no signs of disturbance could be seen, a burial had no doubt taken place at some period more or less remote. The bones have been handed over to the Essex Museum by the Director.

From the top of the pit a good view was obtanned of the Thames to the south and of the Rayleigh Hills, visited last year, to the East.

Good views to the west were also seen later on in the day from the road leading to Horndon beyond the new church, and several roadside sections in gravel examined It appeared that in the sections in the west of the hill the gravel did not contain much, if any, of the Lower Greensand fragments so plentiful in the section already visited

After tea at the "Crown" the President (Mr R. S. Herries) proposed a hearty vote of thanks to the Director, and was supported by the President of the Essex Field Club (Mr Miller Christy) The Director in reply stated that there was still much to learn about the Essex gravels, and he hoped that energetic members of both societies would thoroughly investigate them.

The party returned to London by the 8.30 train.

\section{REFERENCES}

Geolegrical Survey Map, I in. (Drift Edition), Sheet I, S E, 3s.

I880 W. WHITAKER - "Geology of London," p 327-8

I88 "Excursion to Lainden Hills" Proc Geol. Assoc, vol x, p 489 See also The Essex Naturalist, vol i1, pp 126-13I.

1890 Sir J Prestwich - "On the relation of the Westleton Beds, etc" Qua)t Fourn Geol Sic, vol xlvi, p i63

I 901 "Essex Water Supply" J C Thrush, D Sc, p. 70.

1905 SALrER, A E - "On the Superficial Deposits of Central and Parts of Southern England" Proc Geol Assor, vol xix, p 27

EXCURSION TO DORTON, BRILL, AND ARNGROVE. Saturday, JUly 20TH, 1907 .

Director A. Morley Davif's, D.Sc, F G.S. Excursion Secretary, A H. Williams.

(Report by The DiRector)

The party left Marylebone at I 2.I 5 and reached Wotton at I.30. A walk of a mile brought them, now numbering sixteen, to Dorton, where the Director pointed out the position of Brill Hill and Rid's Hill, with the Brickfield at its foot ( $F_{1}$ 20) According to the Geological Survey Map they were then standing in the middle of the outcrop of "Lower Calcareous Grit," here 